\title{
The reliability of bone marrow cytology as response criterion in metastatic neuroblastoma
}

Roswitha Schumacher-Kuckelkorn ${ }^{1}$, Ayad Atra ${ }^{2}$, Maria Luisa Belli ${ }^{3}$, Gerda den Engelsman $^{4}$, Paul Fréneaux ${ }^{5}$, Arnaud Gauthier ${ }^{5}$, Anja Heijlaerts-Klever ${ }^{4}$, Francesca Scuderi $^{3}$, Leonor Senent Peris ${ }^{6}$, Sanjay Tewari ${ }^{7}$, Ondrej Zapletal ${ }^{8}$, Angela Ernst $^{9}$, and Frank Berthold ${ }^{1}$

${ }^{1}$ Childrens Hospital University of Cologne

${ }^{2}$ St George's University Hospitals NHS Foundation Trust

${ }^{3}$ Istituto Giannina Gaslini

${ }^{4}$ Prinses Maxima Centrum voor Kinderoncologie

${ }^{5}$ Institut Curie

${ }^{6}$ La Fe University and Polytechnic Hospital

${ }^{7}$ Royal Marsden NHS Foundation Trust

${ }^{8}$ University Hospital Brno Children's Hospital

${ }^{9}$ University Hospital Cologne

September 11, 2020

\begin{abstract}
Background: The quantitative assessment of neuroblastoma cell content in bone marrow aspirates for response evaluation has been introduced recently. Data on the concordance of interobserver reports are lacking so far. Methods: Investigators of seven European countries representing national reference or large oncological centres convened in 2016. They agreed to quantitatively assess routine bone marrow smears of the participating institutions and to discuss the discrepant results in joint meetings. Results From 2017 through 2019, three cytology rounds with 24, 28, and 28 bone marrow samples were run evaluating the representativity of the smears (yes/(restricted)/no) and the presence of tumors cells (yes/no and \%). The comparison of the reports using $\chi$ (Fleiss) and $\alpha$ (Krippendorff) statistics demonstrated no robust reliabilities. The agreement on the representativity was moderate to poor, on the presence of tumor cells moderate to good and on the percentage of tumor cells slight to moderate. Though the unquestioned value of cytology to detect even tiny metastatic cells in bone marrow, the investigators unanimously agreed that a reliable quantification of the tumor cell content in bone marrow smears is unrealistic. For the key issue of representativity, a new practical definition was developed. Conclusion For any work with bone marrow aspirates the representativity of the material is of paramount importance. A practical definition is proposed. A reliable quantitative cytological assessment of tumor cell content in bone marrow aspirates is not feasible in metastatic neuroblastoma. Therefore its use as response criterion should be re-considered.
\end{abstract}

\section{Hosted file}

BMC_paper_manuscript_final_20.09.09_main_text.doc available at https://authorea.com/users/ 358136/articles/480411-the-reliability-of-bone-marrow-cytology-as-response-criterion-inmetastatic-neuroblastoma

\section{Hosted file}


BMC paper manuscript final 20.09.09 Table 1.doc available at https://authorea.com/users/ 358136/articles/480411-the-reliability-of-bone-marrow-cytology-as-response-criterion-inmetastatic-neuroblastoma

\section{Hosted file}

BMC paper manuscript final 20.09.09 Table 2.doc available at https://authorea.com/users/ 358136/articles/480411-the-reliability-of-bone-marrow-cytology-as-response-criterion-inmetastatic-neuroblastoma 